\title{
Efeito da aplicação de lodo de esgoto na severidade da murcha-de-curtobacterium em feijoeiro
}

\author{
Ronaldo Bueno Rodrigues ${ }^{1,2}$, Tadeu Antônio Fernandes da Silva Júnior ${ }^{1,2}$, Antonio Carlos Maringoni1 ${ }^{1,3}$
}

${ }^{1}$ UNESP - Universidade Estadual Paulista "Júlio de Mesquita Filho", Faculdade de Ciências Agronômicas, Departamento de Produção Vegetal, CP 237, 18603-970, Botucatu-SP, <maringoni@ fca.unesp.br>. ${ }^{2}$ Bolsista de Iniciação Científica da FAPESP, ${ }^{3}$ Bolsista do CNPq.

Data de chegada: 03/06/04. Aceito para publicação em: 04/03/05.

1082

\begin{abstract}
Rodrigues, R.B.; Silva Júnior, T.A.F.; Maringoni, A.C. Effect of sewage sludge application on the severity of curtobacterium wilt in bean plants. Summa Phytopathologica, v. 32, n. 1, p. 82-84, 2006.

This work was aimed at evaluating the effect of different sewage sludge concentrations (SS) on the reduction of the severity of curtobacterium wilt in bean plants (Pérola cultivar), and on plant development (dry mass of the above-ground part of plants), in two assays under greenhouse conditions. In the first assay, SS doses of $0,2.5$, 5.0, 7.5, and $10 \%$ were used. For the second assay, SS doses were $0,0.5,1.0,1.5,2.0$, and $2.5 \%$, incorporated in soil, with previously

corrected $\mathrm{pH}$ and added with chemical fertilizers at the rate recommended for the crop. Plants that had not been inoculated with the pathogen were maintained in both assays. No efficacy was verified for the different SS doses studied in the assays on the reduction of disease severity symptoms, as well as on dry mass of inoculated plants. Concentrations of SS incorporated to the substrate higher than $5 \%$ were toxic to bean plants, reducing dry mass of plants.
\end{abstract}

Additional keywords: Curtubacterium flaccumfaciens pv flaccumfaciens, Phaseolus vulgaris, plant disease control.

\section{RESUMO}

Rodrigues, R.B.; Silva Júnior, T.A.F.; Maringoni, A.C. Efeito da aplicação de lodo de esgoto na severidade da murcha de curtobacterium em feijoeiro. Summa Phytopathologica, v. 32, n. 1, p. 82-84, 2006.

O presente trabalho teve por objetivo avaliar, sob condições de casa de vegetação, o efeito de lodo de esgoto (LE) na redução da severidade de murcha-de-curtobacterium em feijoeiro, cultivar Pérola, e no desenvolvimento das plantas (massa seca da parte aérea). No primeiro ensaio foram empregadas as doses de LE: $0 ; 2,5 ; 5,0$; 7,5 e $10 \%$, e no segundo ensaio as doses de LE: $0 ; 0,5 ; 1,0 ; 1,5 ; 2,0$ e $2,5 \%$ incorporados em solo com $\mathrm{pH}$ previamente corrigido e adu- bado com fertilizantes minerais na dose recomendada para a cultura. Nos dois ensaios foram conduzidas plantas não-inoculadas com o patógeno. Não foi verificado o efeito do lodo na redução da severidade dos sintomas da doença, bem como na massa seca da parte aérea das plantas inoculadas. Concentrações superiores à 5\% de LE incorporado ao substrato foram fitotóxicos às plantas de feijoeiro, reduzindo a massa seca da parte aérea.

Palavras-chave adicionais: Curtubacterium flaccumfaciens pv flaccumfaciens, Phaseolus vulgaris, controle de doença, matéria orgânica

O Brasil é considerado o maior produtor mundial de feijão (2), sendo a cultura do feijoeiro implantada em todo o território brasileiro nos mais variados níveis tecnológicos. O feijão é uma importante fonte protéica e energética, principalmente para a população de baixa renda.

O feijoeiro é uma planta que está sujeita à incidência de um grande número de doenças, causadas por fungos, vírus e bactérias, que podem causar quedas significativas em seu rendimento.
Entre as doenças bacterianas, a murcha-de-curtobacterium, causada por Curtobacterium flaccumfaciens pv flaccumfaciens, ocorre em cultivos comerciais em várias localidades do país (10).

A murcha-de-curtobacterium, por causar quedas significativas na produção, aliada a importância da cultura para a agricultura brasileira, justificam as iniciativas do uso de novas técnicas de controle, principalmente aquelas que resultam em menor impacto ambiental.A possibilidade do uso do lodo de esgoto (LE), 
resultante do tratamento das águas servidas (esgoto), no controle dessa bacteriose, está baseada numa provável indução de resistência à planta. Segundo Hoitink et al. (3), o uso de compostagem e de suas infusões ativar genes de resistência às doenças que afetam tanto o sistema radicular, como a parte aérea das plantas.

Para doenças bacterianas, têm-se o conhecimento dos trabalhos de Mcllveen \& Cole (6) e Prior \& Béramis (8). Os primeiros autores, adicionaram LE ao solo, nas concentrações de 11, 22 e $44 \mathrm{t} / \mathrm{ha}$, e esterco bovino a 11t/ha, na cultura do milho, sob condição de campo, onde não foi observado efeito do LE sobre a murcha bacteriana de Stewart, causada por Pantoea stewartii subsp. stewartii. Mas, o trabalho de Prior \& Béramis (8), em solo infestado por Ralstonia solanacearum, demonstrou redução na incidência da murcha bacteriana do tomateiro, quando foi incorporado LE ao solo. Para a murcha-de-curtobacterium do feijoeiro não foi encontrado trabalho na literatura nacional ou internacional. O presente trabalho teve por objetivo avaliar o efeito de diversas concentrações de LE, incorporado ao solo, sobre a severidade da murcha-de-curtobacterium e sobre a massa seca da parte aérea de plantas de feijoeiro inoculadas e não-inoculadas com o patógeno, sob condição de vaso, mantidos em casa de vegetação.

Dois experimentos foram conduzidos empregando-se a cultivar de feijoeiro Pérola e terra com correção de $\mathrm{pH}$ e adubação mineral recomendada para a cultura. O LE foi incorporado ao solo com a adubação mineral de plantio, dois a três dias antes do transplante das sementes pré-germinadas, em doses diferenciadas de acordo com o tratamento. As doses de LE utilizadas foram $0 ; 2,5 ; 5,0 ; 7,5$ e $10 \%$ (primeiro ensaio) e $0 ; 0,5 ; 1,0 ; 1,5 ; 2,0$ e $2,5 \%$ (segundo ensaio). O LE empregado nos ensaios foi proveniente da Estação de Tratamento de Esgoto de Jundiaí, SP, e sua análise química está relacionada na Tabela 1 .

As sementes usadas no transplantio foram previamente tratadas com captan ( $1 \mathrm{~g} . \mathrm{Kg}^{-1}$ de sementes), proporcionando a erradicação de fungos, acondicionadas em papel "germ-test", umedecidas e colocadas em estufa a $30^{\circ} \mathrm{C}$, durante $48 \mathrm{~h}$, proporcionando a germinação das mesmas. No estádio de emissão da radícula cinco sementes pré-germinadas foram transferidas para vasos de cinco litros de capacidade. Aos dez dias após a emergência das plântulas, foram selecionadas três plantas que foram inoculadas com o isolado Feij-2634 de Curtobacterium flaccumfaciens pv.flaccumfaciens, pelo método de punção com agulha entomológica no caule, entre a folhas primárias e o nó cotiledonar (5). As plantas não inoculadas foram submetidas a ferimentos provocados pela agulha entomológica, previamente molhada em água destilada.

O inóculo bacteriano foi obtido a partir do cultivo prévio da bactéria em $5 \mathrm{~mL}$ de meio nutriente líquido, a $28^{\circ} \mathrm{C}$, por $24 \mathrm{~h}$ e, em seguida, repicada para placas de Petri, contendo meio de cultura NSA e incubadas durante $96 \mathrm{~h}$, a $28^{\circ} \mathrm{C}$.

As plantas foram mantidas em casa-de-vegetação, irrigadas diariamente e pulverizadas semanalmente com agrotóxicos registrados para a cultura, visando o controle de pragas e ácaros.

Aos 28 dias após a inoculação, foi realizada a avaliação da severidade dos sintomas da doença nas plantas, atribuindo notas de 0 a 9, conforme trabalho de Maringoni (5). Após esta avaliação, a parte aérea foi colhida e acondicionada em sacos de papel para a secagem em estufa com circulação de ar forçada $\left(60^{\circ} \mathrm{C}\right)$, até o peso manter-se constante, visando determinar a massa seca das plantas.

O emprego do lodo de esgoto nas doses utilizadas nos dois
Tabela 1. Análise química do lodo de esgoto empregado nos ensaios.

\begin{tabular}{|c|c|c|}
\hline Atributo & Unidade $^{(1)}$ & Teor \\
\hline Fósforo & $\mathrm{g} / \mathrm{kg}$ & 6,3 \\
\hline Potássio & $\mathrm{g} / \mathrm{kg}$ & 1,1 \\
\hline Sódio & $\mathrm{g} / \mathrm{kg}$ & 1,1 \\
\hline Arsênio & $\mathrm{mg} / \mathrm{kg}$ & $<0,01$ \\
\hline Cádmio & $\mathrm{mg} / \mathrm{kg}$ & 7,5 \\
\hline Chumbo & $\mathrm{mg} / \mathrm{kg}$ & 212,8 \\
\hline Cobre & $\mathrm{mg} / \mathrm{kg}$ & 889,5 \\
\hline Cromo total & $\mathrm{mg} / \mathrm{kg}$ & 187,3 \\
\hline Mercúrio & $\mathrm{mg} / \mathrm{kg}$ & $<0,01$ \\
\hline Molibdênio & $\mathrm{mg} / \mathrm{kg}$ & $<0,01$ \\
\hline Níquel & $\mathrm{mg} / \mathrm{kg}$ & 43,0 \\
\hline Selênio & $\mathrm{mg} / \mathrm{kg}$ & $<0,01$ \\
\hline Zinco & $\mathrm{mg} / \mathrm{kg}$ & 1801,8 \\
\hline Boro & $\mathrm{mg} / \mathrm{kg}$ & 10,6 \\
\hline Carbono orgânico & $\mathrm{g} / \mathrm{kg}$ & 296,6 \\
\hline $\mathrm{pH}$ & & 5,3 \\
\hline Umidade & $\%$ & 73,9 \\
\hline Sólidos voláteis & $\%$ & 63,2 \\
\hline Nitrogênio Kjeldahl & $\mathrm{g} / \mathrm{kg}$ & 28,0 \\
\hline Nitrogênio-amoniacal & $\mathrm{mg} / \mathrm{kg}^{(2)}$ & 32,6 \\
\hline Nitrogênio-nitrato-nitrito & $\mathrm{mg} / \mathrm{kg}^{(2)}$ & 187,6 \\
\hline Enxofre & $\mathrm{g} / \mathrm{kg}$ & 25,5 \\
\hline Manganês & $\mathrm{mg} / \mathrm{kg}$ & 665,7 \\
\hline Ferro & $\mathrm{g} / \mathrm{kg}$ & 22,7 \\
\hline Magnésio & $\mathrm{g} / \mathrm{kg}$ & 1,7 \\
\hline Alumínio & $\mathrm{g} / \mathrm{kg}$ & 18,5 \\
\hline Cálcio & $\mathrm{g} / \mathrm{kg}$ & 8,4 \\
\hline
\end{tabular}

${ }^{1}$ Os valores de concentração são dados com base na matéria seca; a concentração para o nitrogênio nas formas amoniacal e nitrato foram determinados na amostra nas condições originais.

ensaios não contribuiu para a redução na severidade dos sintomas da murcha-de-curtobacterium nas plantas de feijoeiro inoculadas. No primeiro ensaio, as notas de severidade dos sintomas variaram de 7,7 a 8,9, e no segundo ensaio, as notas variaram de 8,1 a 8,9 , conforme as doses de lodo de esgoto utilizadas. Foi observado menor peso da massa seca da parte aérea das plantas inoculadas cuja redução em comparação com o peso das plantas não-inoculadas variou de 35,58 a $63,27 \%$ dependendo da concentração de lodo empregada. As maiores concentrações de lodo causaram reduções no peso da massa seca da parte aérea das plan- 
tas não-inoculadas, indicando seu efeito fitotóxico. Pode-se observar uma tendência linear de redução no peso das planta conforme ilustrada na Figura 1. Já, concentrações de 0,5 a 2,5\% de lodo de esgoto propiciaram aumento no peso seco da parte aérea das plantas de feijoeiro não-inoculadas, pelos resultados observados no ensaio 2 (Figura 2). Na literatura há relatos de melhor desenvolvimento de plantas em solos/substrato com a incorporação de matéria orgânica (1).

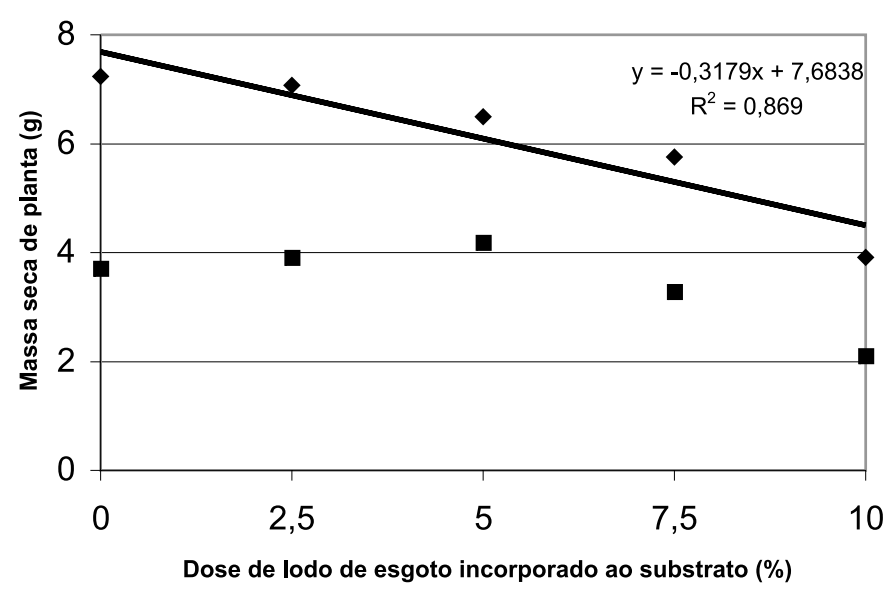

Figura 1. Efeito de diferentes doses de lodo de esgoto no desenvolvimento de plantas de feijoeiro cv. Pérola, não-inoculadas e inoculadas com Curtobacterium flaccumfaciens pv. flaccumfaciens, aos 38 dias após emergência (ensaio 1).

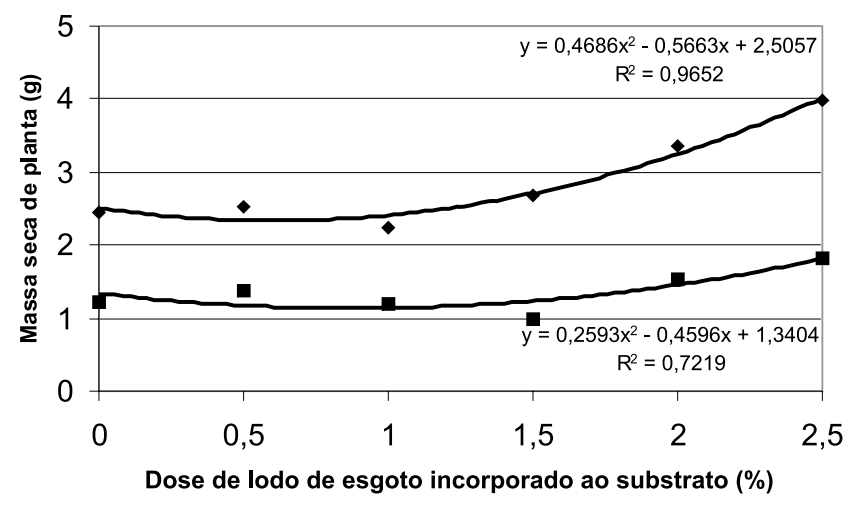

Figura 2. Efeito de diferentes doses de lodo de esgoto no desenvolvimento de plantas de feijoeiro cv. Pérola, não-inoculadas e inoculadas com Curtobacterium flaccumfaciens pv. flaccumfaciens, aos 38 dias após emergência (ensaio 2).
Com relação à murcha-de-curtobacterium, não foi evidenciada a eficácia de controle da doença com a incorporação de lodo de esgoto ao substrato, indicando a não-indução de resistência às plantas de feijoeiro. Segundo Hoitink et al. (3), o emprego de compostagem ativa genes de resistência a patógenos que causam doenças no sistema radicular e na parte aérea. Os resultados aqui observados para a murcha-de-curtobacterium foram semelhantes aos obtidos por Mcllveen \& Cole (6) para murcha bacteriana de Stewart em milho. Esses autores empregaram a adubação com lodo de esgoto, em campo, e não obtiveram sucesso de controle para aquela doença.

Geralmente tem-se resultados satisfatórios de controle de algumas doenças causadas por fungos de solo, em vários patossistemas, por meio da incorporação de LE ao solo ou ao substrato em diferentes dosagens. Pode-se relacionar os exemplos de Sclerotinia minor - alface (4), Pythium arrhenomanes - sorgo (1), Sclerotium rolfssii - feijoeiro e Phytium aphanidermatum - pepino (9). Sugere-se que o controle de patógenos de solo pela adição de LE esteja relacionado com o aumento da microbiota que pode atuar de diversas maneiras sobre a população do patógeno (6).

\section{REFERÊNCIAS BIBLIOGRÁFICAS}

1. Bettiol, W.; Krügner, T.L. Influência do lodo de esgoto na severidade da podridão de raiz do sorgo causada por Pythium arrhenomanes. Summa Phytopathologica, Piracicaba, v.10, n.3, p.243-251, 1984.

2. Empresa Brasileira de Pesquisa Agropecuária - Arroz e Feijão. Importância da cultura do feijoeiro no Brasil, 2002.

3. Hoitink, H.A.J.; Zhang, W.; Han, D.Y.; Dick, W. A. Making compost to suppress plant disease. Biocycle, Emmaus, PA, USA, v.38, p.40-42, 1997.

4. Lumsden, R.D.; Ayers, W.; Dow, R.L. Effect of composted sewage sludge on several soilborne pathogens and diseases. Phytopathology, St. Paul, v.73, p.1543-1548, 1983.

5. Maringoni, A.C. Comportamento de cultivares de feijoeiro comum à murcha-de- curtobacterium. Fitopatologia Brasileira, Fortaleza, v.27, n.2, p. 157-162, 2002.

6. McIlveen,W.D.; Cole JR, H. Influence of sewage sludge soil amendment on various biological components of the corn field ecosystem. Agriculture and Environment, Amsterdam, v.3, p.349361, 1977.

7. Millner, P.D.; Lumsdem, R.D.; Lewis, J.A. Controlling plant disease with sludge compost. Byocicle, Emmaus, PA, USA, v.23, p.50-52, 1982.

8. Prior, P.; Béramis, M. Induction de la résistance au flétrissemente bactérien dû à Pseudomonas solanacearum E.F.Smith chez un cultivar de tomate repute sensible. Agronomie, Paris, v.10, p.391401,1990 .

9. Santos, I. Efeito do lodo de esgoto sobre a atividade microbiana e fitopatógenos habitantes do solo. 2001. 82f. Botucatu, Tese (Doutorado em Proteção de Plantas) - Faculdade de Ciências Agronômicas, Universidade Estadual Paulista, Botucatu.

10. Sartorato. A. Principais doenças do feijoeiro comum (Phaseolus vulgaris L.). Disponível em <http://www.zoonews.com.br/ principais_doencas_do_feijoeiro_comum.htm>. Acesso em: 4 abr. 2005. 